\title{
REPORT OF COMMITTEE ON BREEDING FOR DAIRY PRODUCTION.
}

By Mr. A. J. GLover, Ft. Atkinson, Wis.

Before I proceed to make my report, it is really necessary for me to say a word about it in order that I may not appear ridiculous. I am a member of the Committee on Breeding for Dairy Production, and I prepared a few paragraphs and sent them to the chairman of this committee. Day before yesterday, I received the same back again, the chairman stating that he would be unable to attend, and that I had better present it to the meeting. I have had no time to revise it, and have not had time to prepare a paper. You will therefore understand that what I have here is a suggestion, and nothing conclusive, and that the few thoughts I have to offer lack continuity. When I was asked to make my report to-night I consented, because I thought I had a few things here that would be valuable for the dairy breeders and perhaps breeders of other live stock to consider.

BEAUTY AND UNIFORMITY VS. RECORDS.

Some of the breeders at the present time are breeding largely to animals making the biggest records and with little regard to uniformity and beauty, while too many pay but little or no attention to records but put their entire efforts upon producing stock of beautiful markings and fancy points. Of course, uniformity and beauty have no value so far as the production of the animal is concerned, but is there not something more to breeding than simply getting a type of cows that will produce butter fat and milk economically?

To be useful is the primary aim of life, but that does not mean that the creature must be ugly looking and ill-shaped. In breeding, our chief object should be to breed animals that are large producers, but fancy points should receive some consideration. The question is: How many points out of 100 should be given the productive powers of the animal, and how many to breed characteristics, or to conformance with certain standards outlined by the different breed associations.

This is a point well worth considering even though the primary object of breeding dairy cows is to produce those that are capable; but we must not lose sight of the fact that admirers of fancy stock are willing to pay a long price for the animal that not only rewards him bountifully at the pail but also pleases his eye.

\section{SHORT AND FORCED TESTS.}

Too much emphasis has been laid upon forced tests-such as the weekly, 30-day, and those made at our expositions. These tests show what it is possible for a dairy-bred cow to do in a short time, but they do not reveal her true ability-that is, to produce large yields of milk 
and fat for a series of years, and also produce strong and talented dairy animals. In other words, it is very doubtful to me whether these tests, like those at St. Louis, advertise our dairy cattle in the proper way. For example, perhaps a good-intentioned, but not wellinformed man makes up his mind to breed Jerseys, because they won at St. Louis, and he makes a few purchases, regardless of the ability of the animals. This man, to a certain extent, will expect his Jerseys to do as well as those at St. Louis, and if they do not he is disappointed.

On the other hand, these tests being a great deal like a horse race, the majority of dairymen that read of the results are not stimulated to get better dairy stock, any more than they are led to believe that they should raise trotting horses, because a Dan Patch paces a mile in 1.55 and sells for $\$ 60,000$. They think that this class of cattle is beyond them, and, therefore, they never take interest in them.

Furthermore, too many animals are made useless through the excessive work that they are called upon to do in a short time. Some of the best cows at the St. Louis Fair are now worthless, and their blood lost to the dairy world, because of this test. Is there not some other method that this committee could suggest that will be more effective in getting dairymen to see the importance of purchasing, keeping, and breeding better cows?

\section{WHAT REVEALS PREPOTENOY.}

I wish we could find some data to work on for estimating and teaching the outward indications of prepotency in males. This is the crucial test of their value, yet no one seems to be able to point out how it may be determined.

The Guernsey Cattle Club, in their new scale of points have gone further under the lead of $W$. D. Hoard in the consideration of prepotency, constitution and temperament than any other body of breeders in the United States. Maybe we could do some profitable work along these lines.

\section{HOW SHALL WE BREED TO PRODDCE THE BEST COWS?}

It is easier to ask such a question than it is to answer it. The aim of all breeders should be to produce superior cows. It is quite generally believed that daughters take after their fathers and sons after their mothers, in what might be called "prepotent heredity." Now, if this be in the main true, most breeders are working against the law in their efforts to breed on an improving and upward grade.

They pay much more attention to the quality of the cow, as the parent of heifers, than they do to the bull. The true working of that law would be to the effect that a good cow will reproduce her good qualities, not so much through her daughters as through her sons, to be shown finally in her grand-daughters. 
A diagram of the Darwinian law of descent would be like this:

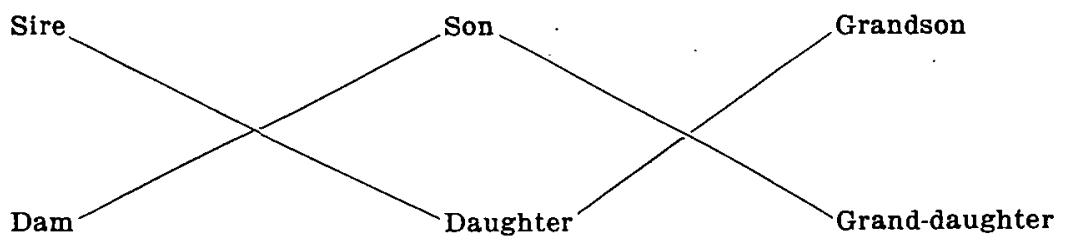

It is important that both the dam and sire should be high class animals. But in the production of good heifers, is it not of more importance that the sire should be richly bred? Who can say with certainty?

\section{THE DAUNCEY THEORY.}

No greater breeder of dairy cattle ever lived than Mr. Philip Dauncey, who developed the Rioter family of Jerseys. His main object in breeding was to create an animal of great strength, in constitution, and capable of producing large yields of milk. He had the faculty of mating animals to produce his ideal, but unfortunately for breeders, this wonderful gift he took with him to the grave. We have, however, seen the results of his work and by this means have been able to judge the kind of animal that he developed.

Mr. Dauncey believed in coarseness rather than in fineness of physique; coarse hair, heavy bones, thick skin, and a coarse head were considered by him indicative of bodily vigor and a constitution that was capable of resisting disease. The ugly looking head is one of the striking characteristics of the Rioter family, which have been noted far and wide as wonderful producing and strongly developed animals.

In the scientific breeding of dairy animals such points as the above should be noted, and in due time there would be tabulated data, which would suggest or indicate whether coarseness of bone, head, and hair, has anything to do with bodily vigor and a diseaseresisting constitution.

\section{WEAT REVEALS CONSTITUTION.}

It is generally accepted among teachers of animal and dairy husbandry that depth and width of thorax are indicative of great lung capacity and large hearts. Too frequently is it said that dairy cattle have not the constitution that the beef animals hate, because they have less heart girth. The measuring of the size of lings in both the dairy and the beef animals has been mostly from external observations. In-Bulletin No. 81 of the Iowa Experiment Station, the weights of the hearts and lungs of 4 dairy and 4 beef steers are given, and I reproduce them in the table on the following page. 
From the table it will be seen that the dairy steers have considerably larger lungs and about the same sized hearts. If the computation is made, per thousand pounds live weight the lungs and windpipes of dairy steers are 54.6 per cent larger than those of the beef steers and the hearts only a trifle larger.

Since so few animals are brought into this calculation I do not feel like laying too much stress upon it. If these figures be true, some other test must be applied besides external observation and measurements in judging the lung capacity of the animal, because, as

Comparative Weights of Heart and Lungs in Dairy and Beef Steers.

\begin{tabular}{|c|c|c|c|}
\hline Class. & Breed. & Hearts. & $\begin{array}{c}\text { Lungs } \\
\text { and } \\
\text { windpipe. }\end{array}$ \\
\hline Dairy steers.......... & $\left\{\begin{array}{l}\text { Jersey } \ldots \ldots \ldots \ldots \ldots \ldots \ldots \ldots \\
\text { Jersey } \ldots \ldots \ldots \ldots \ldots \ldots \ldots \ldots \\
\text { Holstein } \ldots \ldots \ldots \ldots \ldots \ldots \ldots\end{array}\right.$ & $\begin{array}{c}\text { Pounds. } \\
4.0 \\
4.5 \\
3.5 \\
1.5\end{array}$ & $\begin{array}{c}\text { Pounds. } \\
10.0 \\
10.0 \\
11.0 \\
8.5\end{array}$ \\
\hline Average $\ldots \ldots \ldots \ldots \ldots \ldots \ldots \ldots$ & $\ldots \ldots$ & $\mathbf{3 . 4}$ & 9.87 \\
\hline For each 1000 pounds............ & (n........... & 2.89 & 8.42 \\
\hline Beef steers...... & $\left\{\begin{array}{l}\text { Hereford } \ldots \ldots \ldots \ldots \ldots \ldots \ldots \\
\text { Hereford } \ldots \ldots \ldots \ldots \ldots \ldots \ldots \\
\text { Angus } \ldots \ldots \ldots \ldots \ldots \ldots \ldots \ldots \\
\text { Angus } \ldots \ldots \ldots \ldots \ldots \ldots \ldots\end{array}\right.$ & $\begin{array}{l}3.5 \\
6.0 \\
2.5 \\
3.0\end{array}$ & $\begin{array}{l}6.0 \\
8.0 \\
6.5 \\
7.5\end{array}$ \\
\hline Average $\ldots \ldots \ldots \ldots \ldots \ldots \ldots \ldots$ & 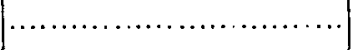 & 3.7 & 7.0 \\
\hline For each 1000 pounds........... & $\ldots \ldots \ldots \ldots \ldots$ & 2.88 & 5.46 \\
\hline
\end{tabular}

a rule, the beef animal is larger in heart girth than the dairy animal. Would it not be well for some experiment station to take up this work and give us more data upon the comparative sizes of the heart and lungs-in the dairy and beef animals; also determine whether the size of the lungs and heart is indicative of a strong constitution. Dauncey laid great stress upon coarse hair, bones, and head; Hoard thinks strong abdominal walls and strong navel development indicative of a vigorous constitution. Here is a field for work.

\section{PRODUCTION AT THE PAIL AND PRODUCTION OF THE WOMB.}

There seems to be a tendency among many of the very highest producing dairy cows to become barren, or, at least, be poor or irregular breeders. It is important that the blood of the best animals should be 
transmitted to their offspring, and in turn through their progeny reproduce themselves if the most desirable qualities, of the best dairy animals, are to be maintained and handed down to the coming generations.

Through the anxiety to make large records with the phenomenal cow, she is often overfed, which from all indications not only injures her digestive organs, but also her powers of reproduction. Overfeeding may be the principal cause for barrenness and irregular breeding. Who can say?

Perhaps another reason may be the high development of the mammary gland, a condition which must obtain to have an exceptional animal. The nervous system in the dairy animal is supposed to be more highly developed than in the beef animal. Is it probable that this condition may have something to do with the breeding power of the high-class dairy cows? The udder is connected with the womb by a wonderful network of nerves called the sympathetic plexus and thence to the lumbar region of the spine. It might be inferred that excessive lactation would have a reflex effect on the womb.

\section{YEARLY VS. SHORT TESTS.}

I think we ought to emphasize the greater importance of the yearly test of cows over the weekly or 30-day test, for the reason that the short-time test is more apt to tempt men over the danger line. Then, too, the yearly test is a better guarantee of the staying power of the cow and her real producing ability.

The Holstein-Friesian Association have a system of testing cows within 30 days after calving and then again in 8 months. The Guernsey Cattle Club test one day each month during the year. The Jersey and Ayrshire breeders have similar tests. But the largest number of official records are made in seven days, which is too short a time to prove the merits or demerits of a cow.

The system of testing cows 30 days after calving and again in 8 months or testing them once a month, through the year, should be encouraged, for both systems give very satisfactory results.

\section{EFFECT OF FEED UPON HEALTH.}

I once had a conversation with the first man to produce certified milk in the United States. He said: "Do you know that I can so feed my cows that I can make every baby that is using my milk sick?" He handed me a number of letters complaining about a certain day's milk, and explained that he had found that that day his cows had been turned from short pasture over into long pasture, thereby becoming more or less sick. This showed that the feed had its direct effect upon the health of the animal and upon its development.

Chairman WARD. Gentlemen, away back, early in the seventies, it was my pleasure to take a trip to California by way of St. Iouis and Denver. On the trip from St. Louis to Denver we were astounded 
by the enormous herds of buffalo along the line of what was then the Kansas Pacific Railroad. They were so thick at one point that the train was obliged to stop for some little time while the herd was crossing the track at this particular point; and while the train was stopping we saw a gentleman with long hair and a broad brimmed hat, and a couple of Colt's navy revolvers and a Winchester rifle hanging on the outskirts of the herd gathering in his crop. We asked who he was, and some one of the same type on the train said, "Why, that is Colonel Jones-Buffalo Jones."

The buffalo now have all disappeared from the plains. Within the past two or three years I passed over the same road and found that even the buffalo bones had disappeared; but Colonel Jones had not disappeared; he still remains upon the scene. He is endearoring at the present time to atone for some of his past misdeeds-what we at the present time consider misdeeds, but which everybody considered all right at that time-and he is now endeavoring to replace not the buffaloes themselves perhaps, but some modifications of the buffalo.

$\mathrm{He}$ is not only breeding buffalo, but he is crossing the buffalo upon our domestic cattle. He has been kind enough to bring us here a show which I am quite sure will interest you all, and he will give you a talk upon the work he is doing.

By the way, the Colonel tells me he does not object to being called "Buffalo Jones."

\section{BREEDING CATTELO.}

By Coloned C. J. Jones, Topeka, Kas.

[Illustrated by moving pictures.]

Mr. Chairman and Gentlemen of the American Breeders' Association: Your Chairman has given me a terrible send-off, and I guess I need it. He has introduced me as "Buffalo Jones," but there is one thing that I want placed to my credit, and that is that, when I found that the animals were liable to be exterminated if their slaughter was continued so wantonly, I determined that I would do my part to make amends by making every effort in my power to prevent their final extinction, and I have to my credit over 1500 buffalo that I have bred. That 1500 originated as nearly as I can figure it up from 82 calves, for you must remember that no animal was ever captured alive and kept alive in captivity that was over three months old at the time of its capture. When you capture them over that age they will commit suicide, you never can save them; conse- 